\title{
Food Systems and Health: Prospects for Hope in the Brazilian Chaos?
}

\author{
Paula Johns ${ }^{1}$ \\ Published online: 23 November 2020 \\ (c) Society for International Development 2020
}

\begin{abstract}
There are several other pandemics, such as NCDs, obesity and climate change that have been ongoing for a while and are now being severely impacted by the COVID-19 pandemic. Are we going to use this convergence as an opportunity to tackle the systemic structures that have been fertile ground for the new COVID-19 pandemic to arise, alongside the older ones? This article will reflect upon the above through a closer look into the intersections between the questions that concern food systems, climate change, health politics and power relations with examples from the Brazilian context. We need inspired, inclusive and compassionate responses to bridge the current mismatch between the size of the problem and the response to it.
\end{abstract}

Keywords NCDs $\cdot \mathrm{UPF} \cdot$ Industrialized agriculture $\cdot$ Amazon region $\cdot$ Family farming $\cdot$ Environmental devastation

'Every storm runs out of rain' - Maya Angelou

\section{Brazil Hanging in the Midst of the COVID-19 Outbreak}

There seems to be more questions than answers about the post COVID-19 world. One of the most fundamental questions, indeed, is whether we are going to have more COVID19 like pandemics in the coming years, and what the world is planning to do to place health for all people and for the planet at the center of a political agenda that brings solutions. Are we going to reinforce or challenge the paradigm of concentration of power in the hands of a few? Are we determined to become wiser or are we going to be carried away in the vortex of more polarization, in a world already inhabited by a growing number of authoritarian governments? Are we going to acknowledge that to achieve wellbeing, without leaving anyone behind, we need to seriously challenge business as usual? COVID-19 has ripped open the catastrophic management of the last 40 years of economic and social planning. More than ever, we now have a grand opportunity to recognize that our human and planetary health and are interwoven. And it has always been like this, by the way.

Paula Johns

paula.johns@actbr.org.br

1 ACT Health Promotion, Rio de Janeiro, Brazil
This article is about how Brazil produces and consumes food. That topic may seem quaintly unconventional, particularly to international readers who at present, when they hear about Brazil, the main things they recall is massive fires in the Amazon, the erratic authoritarian government and a botched response to the COVID-19 pandemic. But discussions around health and food systems are necessary, because they are intertwined with environmental, economic and political issues. Building food systems that are efficient, fair, sustainable and healthy may not only open the way to a better approach to public health as a common good, but also lead society to a less fragmented and more consistent vision of the world. There is hope in the chaos.

The chaos is real, of course. Even prior to COVID-19, Brazil was in a deep economic crisis and an even deeper political crisis, with extreme societal polarization, thriving of fake news, mounting attacks on science, and the rising of old and new inequities. Against this backdrop, the presidential party threatened to override the constitution and imperil democracy by restoring military rule (Austin 2019). ${ }^{1}$ Arguably, Brazil was already facing an epidemic of Non-Communicable Diseases (NCDs), a substantial portion of which are caused by the nation's transition to heavily promoted Ultra-Processed Foods (UPFs) (Noll et al. 2019).

But the hope is also real, and the multiple crises have indeed triggered reactions and built links across organizations, groups and sectors that may potentially pave the

\footnotetext{
1 https://g1.globo.com/mundo/noticia/2019/11/01/declaracao-deeduardo-bolsonaro-sobre-o-ai-5-repercute-na-imprensa-internacional. ghtml.
} 
way for necessary reforms in Brazil, such as the fiscal and political reforms. We may be naturally intersecting a phase of painful ripening of our young democracy. We see the dynamic of terrible news met by hopeful counter-reactions across a range of social, health and environmental issues. Brazil's plundering class, which puts its short-term profits ahead of the country and even ahead of its own children's future, is on the rampage. In the Amazon, rainforest is illegally burnt to provide transnational corporation with new soya fields and pasture that will be barren in a few years, trampling the human rights of indigenous peoples and other vulnerable groups. ${ }^{2}$ Deregulation is rampant, as the current government pushes for economic development at any costwith many politicians brazenly taking a cut of the profits. ${ }^{3}$ On the other hand, Brazil's vibrant civil society has been able to mobilize important segments of the population and of the legislative and judiciary branches to push back and do significant damage control in relevant areas. The intermediate body of highly experienced civil servants is also playing a crucial role in damage control within the executive branch whenever possible.

Opposing forces are also at work in relation to widespread insecurity provoked by exposure to hazardous substances and waste. The recent report to the Human Rights Council by Special Rapporteur Baskut Tuncak highlights Brazil's rapid environmental devastation, alongside the deteriorating human rights record in various areas of the country. ${ }^{4}$ The state has allowed hundreds of thousands of its most vulnerable citizens to be exposed to environmental hazardsperhaps most spectacularly in the collapse of tailings pond dams-but also due to pesticides, smoke from forest fires, asbestos and a range of harmful emissions from factories located directly beside heavily populated residential areas. ${ }^{5}$ Yet again, also in this context, the strength of NGOs and capacity of social movements, as well as the thick network of social solidarity activities, have proven to act as powerful antibodies of societal resistance and resilience. ${ }^{6}$

\footnotetext{
2 https://www.socioambiental.org/pt-br/noticias-socioambientais /dinheiro-paralisado-por-governo-bolsonaro-no-fundo-amazoniachega-a-quase-r-3-bilhoes; https://outraspalavras.net/outrasmidias/nomatopiba-grilagem-devastacao-e-agronegocio-se-entrelacam/.

3 https://outraspalavras.net/mercadovsdemocracia/o-indiscreto-flert e-dos-neoliberais-com-o-estado/

${ }^{4}$ https://www.ohchr.org/en/NewsEvents/Pages/DisplayNew s.aspx? NewsID $=25434 \&$ LangID $=E$. In this regard, see also CETIM, Brazil: the overwhelming report of the Special Rapporteur, 16 January 2020, https://www.cetim.ch/brazil-the-overwhelming-report-ofthe-un-special-rapporteur/.

5 https://terradedireitos.org.br/uploads/arquivos/A_HRC_45_12_ Add.2-.pdf.

${ }^{6} \mathrm{https}: / /$ mab.org.br/.
}

\section{When Food Systems Deliver Global Devastation... and the Struggle for Healthy Alternatives}

Brazil's large agri-business sector accounts for a substantial portion of the country's exports, and its most reactionary elements have tremendous influence on the Bolsonaro government. Extensive, industrialized agriculture has resulted in ever higher yields, greater labour productivity and increasing profits - at least, as long as balance sheets and national accounts ignore the massive socio-environmental costs. As is the case elsewhere, if corporations paid for the use of ecosystems, which they depend on and systematically destroy, they would have to interrupt their operations. Globally, according to a KPMG report, the environmental costs of business operations are doubling every 14 years. A chart that compares the environmental costs of production in various sectors of the global economy with gains explains how these costs soar up to $224 \%$ of business earnings in the agri-food sector. ${ }^{7}$ This is a bright red indicator of the urgency of the problem which, translated in the real world disasters, means setting intentional fires in the Amazon to clear tracts of land for crops and livestock for export-a long-time problem that has rebounded to record levels under Bolsonaro, who dismisses concerns about deforestation as intolerable foreign meddling. This year in particular, Amazon faces' the perfect storm' of forest clearance, the free riding coronavirus and wildfires, making its people far more vulnerable to the pandemic. In the context of COVID-19, land invasions by timber poachers and miners and the uncontrolled spread of the contagion present a deadly dual threat for indigenous people in the Amazon region. ${ }^{8}$

Brazil's drive to further expand agricultural production is also driving the introduction of hundreds of new pesticides, including categories forbidden in other countries, without any concern for the precautionary principle. The authorizations usually come via corrupt transactions with massive conflicts of interests. ${ }^{9}$ At the same time, the critique about shortsighted productivism is well entrenched in Brazil too. Often at great personal risk, environmentalists and advocates for indigenous rights have not only documented specific deforestation and pesticide-related criminality, but also repeatedly proposed more sustainable economic pathways, where environmental, health and human rights impacts are well

\footnotetext{
7 https://clf.jhsph.edu/sites/default/files/2020-02/true-cost-for-foodsystem-reform-2020.pdf.

${ }^{8}$ https://www.nationalgeographic.com/history/2020/06/disasterlooms-indigenous-amazon-tribes-covid-19-cases-multiply/; https:// www.socioambiental.org/pt-br/noticias-socioambientais/todo-mundo -pegou-aldeia-no-alto-rio-negro-fez-ritual-de-protecao-para-vencer-acovid-19.

9 https://contraosagrotoxicos.org/dados-sobre-agrotoxicos/.
} 
accounted for and more promising agro-ecological models are developed, sustained or revived. ${ }^{10}$

Beyond Brazil's role as a testbed for food policies, good and bad, what happens here directly affects the whole world, and indeed, the future of the planet. The role of deforestation in the global climate emergency is well known; what is perhaps less widely appreciated is the Amazon's role as a reservoir of biodiversity. Currently, the world's population is more and more dependent on a shrinking diversity of foods ( $60 \%$ of calories consumed by humanity comes from three grains - corn, rice and wheat). This limited diversity presents a huge risk, particularly that of a devastating crop failure (e.g. a new fungus that destroys a large portion of the food supply).

Brazil, in its Amazon region alone, is home to thousands of species and varieties of food, many known only to local inhabitants, usually indigenous. Therefore burning the forest so consumers in North America and Europe can eat cheaper hamburgers is more than just unjust-it is also incredibly short-sighted.

The Brazilian state does not just turn a blind eye to the destruction of the Amazon rainforest-it actively subsidizes the agri-business sector that profits when the forest burns. ${ }^{11}$ Hence, here too the world has a vital interest in the return of sanity to Brazilian politics.

It helps that there is a large social base for resistance to the extensive agri-business model: the more than four million small landholders in the country. ${ }^{12}$ Family and smallscale farming has a central role to play in the availability of food and territorial development. There are many regions and examples in which family farming and agroecological practices provides decent livelihoods from the land. Even where short-term yields are below those from industrial agriculture, family farming and agroecology (Wezel et al. 2009). ${ }^{13}$ can provide a better route to socially and environmentally sustainable land stewardship: farmers care about their neighbors and about the environment they and their children live in.

Moreover, family farming gets crucial support from longstanding government procurement policies for institutions

\footnotetext{
10 https://agroecologia.org.br/; https://aba-agroecologia.org.br/sobre -a-aba-agroecologia/sobre-a-aba/.

11 https://br.boell.org/pt-br/2016/09/06/atlas-da-carne-fatos-e-numer os-sobre-os-animais-que-comemos.

12 https://sidra.ibge.gov.br/pesquisa/censo-agropecuario/censo-agrop ecuario-2017.

13 https://www.foodsovereignty.org/wp-content/uploads/2015/02/ Declaration-of-the-International-Forum-for-Agroecology-Nyele ni-2015.pdf.

14 http://www.fnde.gov.br/programas/pnae/pnae-eixos-de-atuacao/ pnae-agricultura-familiar.
}

such as schools, ${ }^{14}$ and other public institutions. ${ }^{15}$ Speaking of school environments, the Brazilian public education network offers daily meals to 43 million children, in an operation capable of mobilizing an entire system for the production, supply and preparation of food. These policies (though now under threat) give preference to purchases of locally produced food from small farms. When authorities buy food for Brazil's massive school meals programme, it is essential they continue to use their considerable purchasing power to provide steady business for family farms, which are then better able to offer a wide variety of quality foods and products to local markets. This approach has immediate healthy implications on adult and children's dietary habits, as it prevents the emergence of chronic diseases that heavily condition individual and family lives, as well as the national health system. Resorting to family farms' food, moreover, has an inherently regenerative outcome not only in supporting sustainable farming. It can reduce and minimize the waste of material and energy resources inherent in the concentration of distribution in the hands of metropolitan wholesalers; it can also regenerate ecosystems and reduce inequalities. Ultimately, it is the space par excellence for building a new relationship between food, health and environment through education.

It is unfortunate that the COVID-19 puts this family farming at risk, when it comes to provision to the public infrastructures. The pandemic has severely deteriorated access to fresh food in Brazil, particularly for residents in low-income areas. This is true even for those that receive food donations on a regular basis: most food baskets contain processed, nonperishable foods because they are easier to handle, store, and distribute. The closure of schools and day care centres across the country during the pandemic has also deprived children and adolescents of the one daily healthy meal that they were guaranteed to receive (Duarte et al. 2020).

\section{Food Consumption and Nutrition}

While the production side of the Brazilian food system, skewed for global markets, is a perfect recipe for ecological disasters and viral spillovers, the area where Brazilian policy is worth emulating has to do with the consumption side of food systems. I refer to the 'Food Guidelines for the Brazilian Population' released by the Ministry of Health in 2014. ${ }^{16}$ It promotes a novel approach to nutritional guidance

\footnotetext{
15 https://www.gov.br/cidadania/pt-br/acoes-e-programas/inclusaoprodutiva-rural/paa/paa-ci.

16 https://www.fsp.usp.br/nupens/wp-content/themes/nupens/assets/ pdf/dietary_guidelines_brazilian_population.pdf.
} 
by focusing on socially and culturally contextualized dietary patterns.

A bit of context may be helpful for readers from nonnutrition backgrounds. For decades, nutrition discussions tended to focus on individual nutrients and/or 'bad' substances (fat, sugar, salt etc.) in people's diets. In international development circles, this tended to lead to a focus on getting specific nutrients to the population and on boosting calorie counts to avoid starvation. In high-income countries, where a substantial proportion of food is purchased in processed form, it has led to an emphasis on encouraging consumers to reduce their intake of 'bad' substances, e.g. by purchasing a different brand of boxed breakfast cereal, one with less sugar.

This approach has not succeeded in reducing steady rises in obesity and diet-related illness in many high-income countries and, increasingly, in middle-income countries also. While the causes of these trends are hotly debated, in recent years attention has focused on shifts in dietary patterns to heavy consumption of ultra-processed foods (UPF). ${ }^{17}$ Critics have come to refer to UPFs as the 'new tobacco', comparing the business model of the ultra-processed foods and beverage industries to that of the tobacco industry (Monteiro and Cannon 2012; Capewell and Lloyd-Williams 2018).

Brazil is a middle-income country with high inequality, where UPFs are aggressively promoted in the media and at retail. And yet, compared to some middle-income countries, it has had less of a rise in obesity. A key reason for this is the resilience of traditional dietary patterns: more so than in other comparable countries, Brazilians continue to buy traditional local foods, cook them and take the time to eat real meals.

Brazil's food guide aims to build on this resilience. ${ }^{18}$ It is based on the NOVA classification, a concept coined by a Brazilian group of researchers that classifies food according to levels of processing and introduces the concept of ultra-processed foods. It is a bold move towards a more holistic approach to food systems and its connection with health (Ahmed et al. 2019; Scrinis 2020) It also has a social and commercial dimension: ultra-processed foods are primarily produced by large transnational and food processing

\footnotetext{
17 https://en.wikipedia.org/wiki/Ultra-processed_food.

18 The guide is organized around 5 principles. The first states that diet, as well as involving nutrients, is about foods, meals, and eating modes, and also includes social and cultural aspects of dietary practices. The second states that sound dietary recommendations are tuned to changes in food supplies and population health patterns. The third acknowledges the interdependence between healthy diets and the social and environmental sustainability of the food system. The fourth states that reliable recommendations on diet come from a range of sources of evidence. The fifth states that dietary guidelines should enlarge people's choice of and right to adequate and healthy diets.
}

companies that have an impact in the sustainability of food systems (Scrinis 2020). ${ }^{19}$ In short, alongside its climatedestroying industrial livestock farming, Brazil has a worldleading food guide and a vibrant family farming sector that provides a wide range of nutritious and environmentally sustainable foods. But just as food production is contested terrain, so too is the right to healthy and sufficient food.

The first action of Bolsonaro's rule was to abolish CONSEA (the National Council for Food Security), ${ }^{20}$ which was re-established in 2003 by former president Lula da Silva to be a mechanism of social participation and oversight in the formulation, monitoring and evaluation of food and nutritional security policies with the objective of attaining the right to food in accordance with the Federal Constitution and in collaboration with the instances from the System for Food and Nutrition Security established by The Law for Food and Nutrition Security. ${ }^{21}$ But the bonds built within Brazil's institutional mechanisms for social participation cannot be extinguished by a presidential decree. The National Health Council (NHC), established in $1937,{ }^{22}$ is an example of an institution that has survived several storms and cannot be extinguished. The NHC played a fundamental role in the creation of the Universal Health System (SUS) and still plays a major role in its defense and strengthening.

After roughly a decade where improved welfare programmes and broad growth substantially reduced food insecurity, Brazil has jumped backwards due to the political and economic crisis. The latest Brazilian Food Insecurity Scale (EBIA) data from the Brazilian Geographical and Statistical Institute (IBGE - POF 2017-2018), released in September 2020 , shows that it took us less than 5 years to get back to the levels of food insecurity of 15 years ago. ${ }^{23}$

The COVID-19 is now exacerbating Brazil's chronic structural problems of food insecurity and food inequity. A recent UNICEF survey ${ }^{24}$ revealed that Brazilian low-income households with children and adolescents have been most hit by the sudden drop in incomes during the crisis, leading in turn to greater food insecurity and higher consumption of unhealthy foods. 'Around 63 per cent of families living with children and adolescents saw their income decline

\footnotetext{
19 http://www.ipes-food.org/images/Reports/Concentration_FullR eport.pdf.

${ }^{20}$ http://www4.planalto.gov.br/consea/acesso-a-informacao/institucio nal/o-que-e-o-consea.

${ }^{21}$ http://www4.planalto.gov.br/consea/conferencia/documentos/leide-seguranca-alimentar-e-nutricional.

${ }^{22} \mathrm{http} / / /$ conselho.saude.gov.br/historico-cns.

23 https://biblioteca.ibge.gov.br/index.php/biblioteca-catal ogo?view $=$ detalhes\&id $=2101670$.

${ }^{24}$ https://www.unicef.org/brazil/comunicados-de-imprensa/familiascom-criancas-e-adolescentes-sao-vitimas-ocultas-da-pandemia-revel a-pesquisa-do-unicef.
} 
significantly. Some 27 per cent even faced periods with neither food nor money to buy food, while 31 per cent said that they had moved towards an "industrial diet". These figures are even higher for the poorest sectors of the population' (Duarte et al. 2020). It is of course scandalous that food insecurity can exist in a country as vast and fertile as Brazil, which prides itself on being a major agricultural exporter. Clearly the challenge is not producing food in sufficient quantity, but rather structuring the food system - and the distribution of income-so that healthy food is widely available and affordable. And we also need to curb a range of wasteful agri-food industry practices that result in widespread spoilage and waste.

\section{Public Health is as Brazilian as Samba}

Brazil is the world's leading exporter of cigarette leaf, which is grown particularly in temperate southern regions, but despite the strength of the huge economic tobacco interests and the Brazilian political system's historic corruptibility, Brazil has also been one the first WHO members states to introduce strong restrictions on smoking and the tobacco industry, after the international health community reached consensus on the Framework Convention on Tobacco Control (FTCT) in 2003. ${ }^{25}$ Brazil was the second country in the world to introduce health warnings with photographs on cigarette packs. It bans smoking in public places and has comparatively high taxes. These policies have worked exceedingly well, thanks in part to a well-developed public health network at the federal and state levels, as well as many actives NGOs. They have given Brazil a sharp drop in smoking prevalence, of more than $50 \%$ in the last 20 years (Levy et al. 2012).

In part because of this experience that Brazil's burgeoning advocacy community has transferred some lessons from tobacco to the food arena. We are debating and promoting the prohibition of marketing of UPF, adoption of front of packaging warning labels to better alert consumers, increasing taxes and regulating school environments. ${ }^{26}$ The advance of ultra-processed products, promoted by aggressive marketing techniques, facilitated access through artificial prices (not accounting to the real cost of its products), misinformation in labels and the growing population distance from real food production have definitely generated the need to invest in food literacy. What came naturally to past generations now needs to be taught. Schools are privileged spaces for that, since they also reach out to children's families, teachers, i.e. a much larger population than kids and students.

\footnotetext{
25 https://www.who.int/fctc/text_download/en/.

${ }^{26}$ https://alimentacaosaudavel.org.br/.
}

Therefore, strengthening existing school feeding policies, such as the National School Feeding Program (PNAE), including the restriction of ultra-processed foods availability and marketing in those spaces, continues to be a priority medicine, if the government is serious about the health of the new generations.

Taxation policies for UPFs also deserve to be highlighted as a not yet utilized path to improve health indicators in Brazil. As part of the current debates about the fiscal reform, taxation of sugary beverages is gaining momentum within the scope of products with negative externalities for both the environment and for health. Furthermore, adding to global evidence, ${ }^{27}$ a recent study in Brazil shows that increasing sugary and artificially sugary beverages taxes is a measure good for health and for the economy. ${ }^{28}$ Rather than tax sugary beverages, the Brazilian state actually subsidizes themnotably the major soda companies, including Coca-Cola, which operate in the so-called free trade zone in the Amazon. ${ }^{29}$ By conservative estimates, this provides them with close to half a billion dollars in tax concessions-privileges given to a sector that has a huge health and also significant environmental impact in the country. ${ }^{30}$

\section{Hope for the Future?}

In Brazil as elsewhere in the world, the COVID-19 pandemic has shone a cruel light on the dysfunctions of politics and the inequalities and injustices that afflict us. It has also created an immense appetite for change, a widespread feeling that we do not want to return to the pre-pandemic status quo ante - which in the case of Brazil was already hair-raising.

Most of the things that really matter in life have no value under the economistic thinking that has dominated our politics and destroyed our health, alongside the planet's. This indicates that the definition of wealth based on GDP fails to account for the human values that inspire us and make us happy.

We need to build a world in which all people can do well in an environment that is doing well. It is inspiring to hear what some visionary leaders are discussing in some corners

\footnotetext{
27 https://www.bbhub.io/dotorg/sites/2/2019/04/Health-Taxes-toSave-Lives.pdf.

28 https://actbr.org.br/post/impacto-sistemicos-das-mudancas-nopadrao-de-consumo-de-bebidas-acucaradas-adocadas-ou-nao-devid o-aos-diferentes-cenarios-de-tributacao/18623/.

29 https://ojoioeotrigo.com.br/2018/01/cocas-happiness-factory-is-inthe-brazilian-amazon-and-is-not-cool/.

30 https://www.nexoj ornal.com.br/ensaio/2020/A-destr ui\%C3\%A7\%C3\%A3o-da-Amaz\%C3\%B4nia-e-o-subs\%C3\%ADdio -aos-refrigerantes.
} 
of the world. ${ }^{31}$ Although our current political leadership in Brazil is trying to turn back the clock, the welfare revolution of the last couple of decades, alongside our social mobilization power and social participation structures, have taught us that things CAN and DO change. Millions in Brazil across multiple issues understand that all those issues are interrelated and that the stakes are high and that together we are the majority of the population.

Last, but not least, hope is a powerful mobilizer.

And I close that with another quote from the inspiring Maya Angelou:

Do the best you can until you know better. Then when you know better, do better.

\section{References}

Ahmed, Selena, Shauna Downs, and Jessica Fanzo. 2019. Advancing an Integrative Framework to Evaluate Sustainability in National Dietary Guidelines, Frontiers Sustainable Food Systems, 25 September, https://www.frontiersin.org/articles/10.3389/fsufs .2019.00076/full.

Austin, Henry. 2019. Bolsonaro's son criticised for suggesting Brazil's government adopt dictatorship-era tactics, 1 November, https:// www.independent.co.uk/news/world/americas/brazil-jair-bolso naro-far-right-eduardo-bolsonaro-military-dicatatorship-a9180 256.html.

Capewell, Simon, and Ffion Lloyd-Williams. 2018. The role of the food industry in health: lessons from tobacco? British Medical Bulletin 125 (1): 131-143. https://doi.org/10.1093/bmb/ldy002.
Duarte, Andrè, Lars M. Sanchez, Michele E. Martins, and Vinícius Picanço. 2020. From Field to Favela: Tacking Food Inequality in Brazil, London School of Economics and Political Sciences, 23 October, https://blogs.lse.ac.uk/latamcaribbean/2020/10/23/fromfield-to-favela-tackling-food-inequality-in-brazil/.

Levy, David, Liz Maria de Almeida, and Andre Szklo. 2012. The Brazil SimSmoke policy simulation model: the effect of strong tobacco control policies on smoking prevalence and smoking-attributable deaths in a middle income nation, PLoS Med: 9(11):e1001336. https://pubmed.ncbi.nlm.nih.gov/23139643/.

Monteiro, Carlos A., and Geoffrey Cannon. 2012. The impact of transnational "Big Food" companies on the south: A view from Brazil. PLoS Med 9 (7): e1001252. https://doi.org/10.1371/journ al.pmed.1001252.

Noll, Priscilla Rayanne e Silva, Matias Noll, Luiz Carlos de Abreu, Edmund Chada Baracat, Erika Aparecida Silveira, and Isabel Cristina Esposito Sorpreso. 2019. Ultra-processed food consumption by Brazilian adolescents in cafeterias and school meals. Scientific Reports 9, 7162. https://doi.org/10.1038/s41598-019-43611-x.

Scrinis, Gyorgy. 2020. Reframing malnutrition in all its forms: A critique of the tripartite classification of malnutrition, Global Food Security, Volume 26, September, https://www.sciencedirect.com/ science/article/abs/pii/S221191242030050X.

Wezel, A., Stéphane Bellon, T. Doré, Charles A Francis, Dominique Vallod, and Christophe David. 2009. Agroecology as a science, a movement and a practice. A review. Agronomy for Sustainable Development, 29: 503-515, https://link.springer.com/artic le/10.1051/agro/2009004.

Publisher's Note Springer Nature remains neutral with regard to jurisdictional claims in published maps and institutional affiliations.

31 https://www.theguardian.com/world/2020/apr/08/amsterdamdoughnut-model-mend-post-coronavirus-economy. 